\title{
FLEXURAL BEHAVIOR OF REINFORCED CONCRETE BEAMS MADE WITH ORDINARY AND HIGH STRENGTH CONCRETES: EFFECT OF INTERFACIAL ROUGHNESS BETWEEN OLD AND NEW CONCRETES
}

\author{
Youkhanna Zayia DinKha ${ }^{*}$, JAMES H. Haido ${ }^{* * *}$ and MSheER HaSAn Ali ${ }^{* * *}$ \\ ***** Dept. of Civil Engineering, College of Engineering, University of Duhok , Kurdistan Region-Iraq
}

\begin{abstract}
Present endeavor is devoted to investigate the flexural strength of beams fabricated by ordinary concrete (OC) and retrofitted with high strength concrete (HSC). Old part of beams is represented the deteriorated concrete; while the new part is referred to retrofitted portion of the deteriorated beam. Bond strength between two concrete parts of beam was enhanced via preparing rough interfacial surface in various ways, namely, sand blast, holes, grooves and steel brush. Experimental measurements are given in terms of flexural load - deflection relationship and cracking pattern of the beams. It is demonstrated that the beams with sand blast interfacial surface show reasonable performance with high flexural toughness and safer cracking at collapse.
\end{abstract}

KEYWORDS: Beam toughness, Bond between old and new concrete, Hybrid concrete beams

\section{INTRODUCTION}

$\mathbf{U}$ nder aggressive environmental circumstances, structural reinforced concrete members show undesirable behavior in terms of their structural durability. Thus, the rehabilitation approaches of these deteriorated structures should be effective, economical and reliable (Tayeh et al, 2013). This goal can be achieved using concrete with high strength and low permeability and porosity in retrofitting purposes (Alaee, 2003; Farhat, 2007; Farhat, 2010; Brühwiler, 2008; Denarie', 2006; Rossi, 2002; Habel, 2004).

Bond between old and new concretes depends on the moisture condition of the interface between them and composition of rehabilitation material (Shin and Wan, 2010). In addition, the roughness of the existing substrate (old concrete) surface plays reasonable role in improving bond strength of the interfacial surface between old and new concretes (Julio et al, 2004). Some techniques were used in previous works (Bett et al, 1988; Alocer and Jirsa, 1990; Alcocer, 1993; Ramirez et al, 1991; Rodriguez and Park, 1994; Stoppenhagen et al, 1995; Hindo, 1990; Silfwerbrand, 1990; Saucier and Pigeon, 1991; Abu-Tair et al, 1996; Talbot et al, 1994; Emmons, 1994; Austin et al, 1995; Sarkar, 2010; Harris et al, 2011; Santos and Julio, 2011; Tayeh et al, 2012) to improve the roughness of this surface and consequently increase the bond strength. Even though many aforementioned research works were launched to study the behavior of hybrid concretes with treated interfacial surfaces but little information is available on the relation to the hybrid (retrofitted) concrete beams and effective treated interfacial surface.

\section{RESEARCH SIGNIFICANCE}

Many concrete structures in Iraqi Kurdistan Region are suffering from damages due to severe environmental conditions. To repair the deteriorated concrete structures and improve the structural behavior, patching with modern constructional repairing materials such as high strength concrete with low permeability are required. Using waste materials available in the local environment with high amount in fabrication of concrete with high performance and retrofitting of deteriorated members is one of considerable local environmental protection plans. The successful rehabilitation of deteriorated concrete members is strongly dependent on the treatment of interfacial surface between old and new concrete as well as the performance of the member. The findings of the present investigation can be promptly adopted in repairing of concrete beams with high strength concretes made from local waste glass and reactive powder of silica fume. Different treatment manners for the interface 
surface to increase its roughness are selected in the present work to show the efficiency of these methods in hybrid beam behavior.

\section{MATERIALS AND METHOD}

\subsection{Concrete Composition}

For the concrete work, ordinary Portland cement was utilized with density and fineness of $1400 \mathrm{~kg} / \mathrm{m}^{3}$ and $2250 \mathrm{~cm}^{2} / \mathrm{kg}$, respectively.

Natural sand was used as fine aggregate with grades as listed in the Table 1. The grading complies with the ASTM C33 (2003) specifications as shown also in Table 1 .

Crushed gravel was employed too in concrete mix as coarse aggregate with maximum grain size of $22 \mathrm{~mm}$.

In curing and mixing of fresh concretes, ordinary tap water was utilized. This water was fresh, potable, odorless, colorless, tasteless and free from organic materials.
Table (1): Grading of the sand

\begin{tabular}{ccc}
\hline Sieve & \% passing & \% specification (ASTM C33) \\
\hline 4.75 & 97 & $95-100$ \\
\hline 2.36 & 85 & $80-100$ \\
\hline 1.18 & 68 & $50-85$ \\
\hline 600 & 54 & $25-60$ \\
\hline 300 & 19 & $10-30$ \\
\hline 150 & 4 & $2-10$ \\
\hline
\end{tabular}

HSC was produced using two types of powders (Fig. 1), namely, reactive powder of silica fume and inert powder of waste glass powder with density and specific gravity of $1300 \mathrm{~kg} / \mathrm{m}^{3}$ and 2.6 , respectively. The physical and chemical properties of the silica fume used are given in Table 2. High strength concrete was utilized to make half of the beam which represents the new concrete part. Thus, the beam is composed of old ordinary concrete half retrofitted with new HSC.
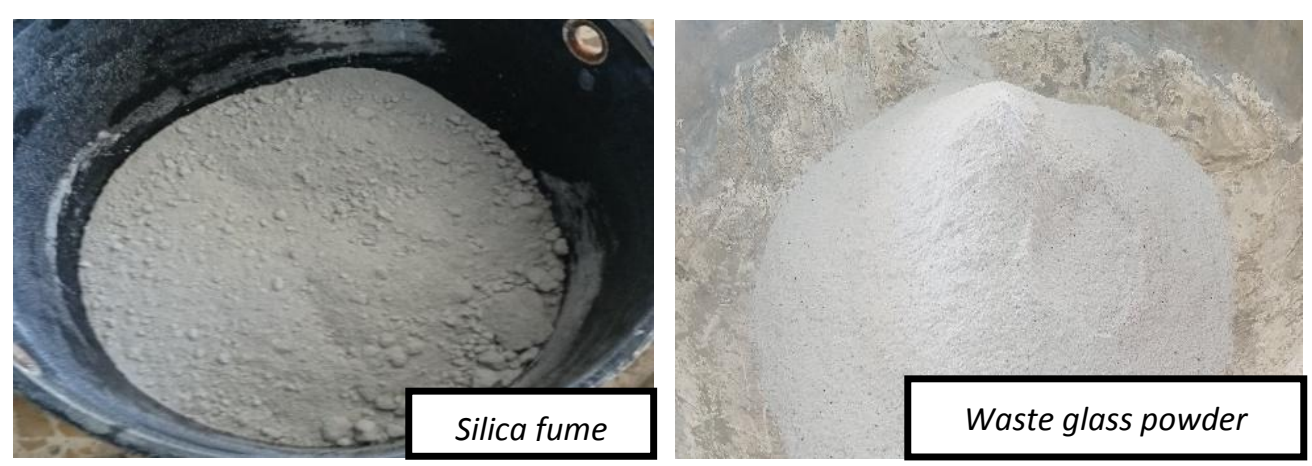

Fig. (1): Powders used in high strength concretes

Table (2): Characteristics of silica fume

\begin{tabular}{cc}
\hline Property & Magnitude \\
\hline$\%$ Retain on 45 micron sieve & 2 \\
\hline Pozzolanic activity \% & 128 \\
\hline Bulk density $\mathrm{kg} / \mathrm{m}^{3}$ (loose) & 1002 \\
\hline$\%$ Moisture content at $105^{\circ} \mathrm{C}$ & 0.06 \\
\hline$\%$ Loss on Ignition at $750^{\circ} \mathrm{C}$ & 0.38 \\
\hline$\%$ Silicon Dioxide $(\mathrm{SiO})$ & 92.4 \\
\hline
\end{tabular}

Gold-colored and brass coated straight steel fibers (Fig. 2) were used in HSC with length of 30 $\mathrm{mm}$ and diameter of $0.45 \mathrm{~mm}$. These fibers were introduced in HSC mix for hybrid concrete beams to enhance the toughness and ductility of the member under transverse loading. 


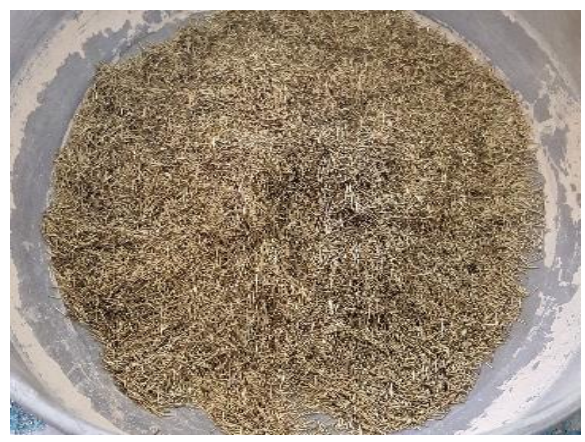

Fig.(2): The steel fibers used

Superplasticizer with content of $2 \%$ by weight of cement was used in HSC to improve the workability of the fresh concrete and durability of hardened concrete. The properties of this admixture are given in Table 3.

Table (3): Properties of Superplasticizer at $25^{\circ} \mathrm{C}$

\begin{tabular}{cc}
\hline Freezing point & $-\mathbf{3}^{\circ} \mathbf{C}$ \\
\hline Color & Light yellow \\
\hline Specific gravity & $1.05 \pm 0.02$ \\
\hline Air entrainment & $<2 \%$ \\
\hline
\end{tabular}

Aforementioned materials were used by weight proportions to manufacture normal concrete and HSC as given in Table 4.

Table (4): Mix design of normal concrete and HSC

\begin{tabular}{cccccccccc}
\hline Mixes. & \multicolumn{1}{c}{ Materials $\mathbf{~ K} / \mathbf{m}^{3}$} & \multicolumn{4}{c}{ Strength at 28days (MPa) } \\
\cline { 2 - 9 } & $\mathrm{C}$ & $\mathrm{S}$ & $\mathrm{G}$ & $\mathrm{GP}$ & $\mathrm{SF}$ & Steel Fiber & Water & SP & \\
\hline $\mathrm{N}$ & 350 & 630 & 1225 & - & - & - & 175 & - & 35.4 \\
\hline HSC-SF & 934 & 1030 & - & - & 234 & 187 & 215 & 40 & 145 \\
\hline HSC-GP & 934 & 1030 & - & 234 & - & 187 & 215 & 40 & 90 \\
\hline
\end{tabular}

Note: $\mathrm{C}=$ Cement, $\mathrm{S}=\mathrm{Sand}, \mathrm{G}=$ Gravel, $\mathrm{SF}=$ Silica Fume, GP= Glass Powder, $\mathrm{SP}=$ Superplasticizer

\subsection{Preparation of Hybrid Beams and Flexural Testing}

Hybrid beam with dimensions shown in Fig. 3 is adopted for flexural tests. The beam is composed of two parts, namely, ordinary reinforced concrete (old part) and HSC as new part. The ordinary concrete half (Fig. 4) was casted and cured in water bath for 28 days at laboratory temperature of $20 \pm 2 \mathrm{C}^{\circ}$. The interface angle was 30 degrees between old and new concretes, and was treated to be rough surface using sand blast, steel brush, grooves with depth of $1 \mathrm{~cm}$, holes with $1 \mathrm{~cm}$ deep as depicted in Fig. 4. Control samples were manufactured using ordinary reinforced concrete beam and hybrid beam without any treatment of interfacial surface. The other half of some beams was made with reactive powder concrete made with silica fume cured in common and accelerated curing due to high cement content and to reduce the time of curing. The specimens were cured for 4 days in an accelerated curing bath at temperature of $100^{\circ} \mathrm{C}$, then, normal curing of the samples was performed for 28 days at lab temperature. Other hybrid beams were fabricated by normal concrete (old part) and HSC made with above-mentioned inert waste glass powder. Accordingly, beams were prepared as listed in Table 5. 

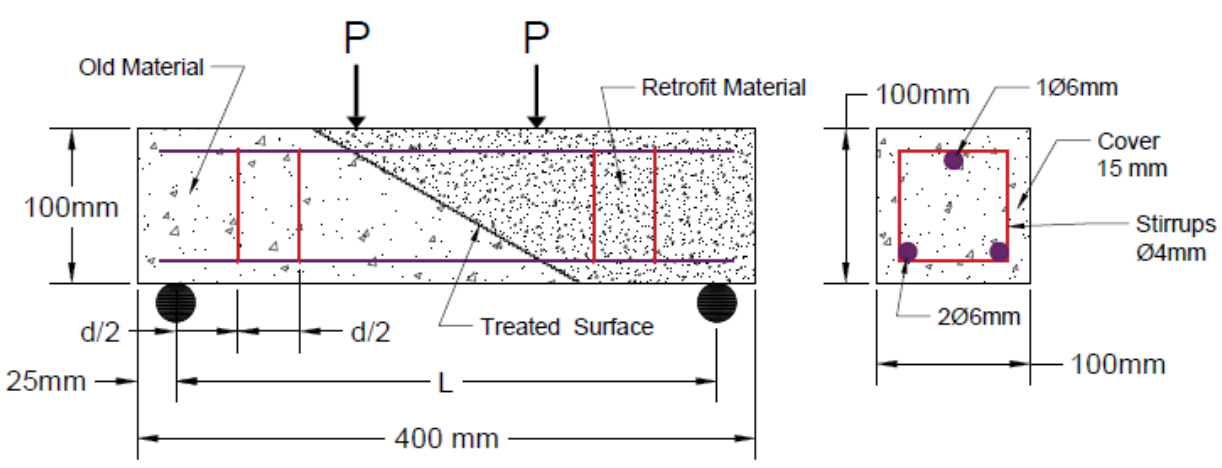

Fig. (3): Testing layout of the hybrid beam

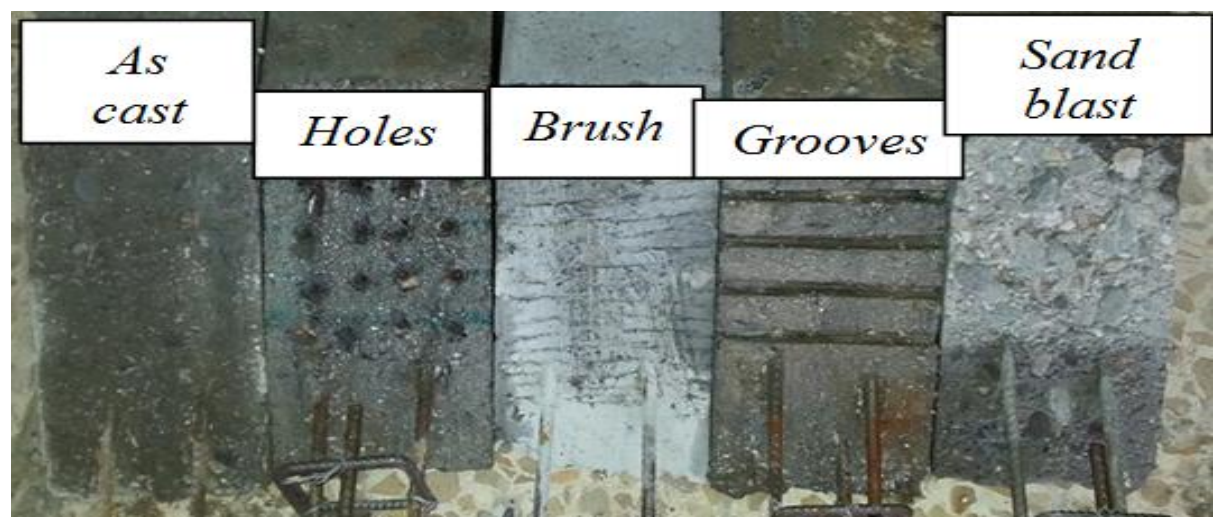

Fig. (4): Interface between ordinary and high strength concretes

Table (5): Reinforced concrete beam samples

\begin{tabular}{ccc}
\hline Beam designation & The used powder & Beam type and treatment of interface between OC and HSC \\
\hline Control & - & Beam made with ordinary concrete and no interfacial surface \\
\hline AC-SF & silica fume & Hybrid beam without any treatment of interfacial surface \\
\hline BR-SF & silica fume & Hybrid beam with steel brush treatment of interface \\
\hline SB-SF & silica fume & Hybrid beam with sand blast treatment of interface \\
\hline DH-SF & silica fume & Hybrid beam with drill hole treatment of interface \\
\hline GR-SF & silica fume & Hybrid beam with grooved treatment of interface \\
\hline AC-GP & Waste glass powder & Hybrid beam without any treatment of interfacial surface \\
\hline BR-GP & Waste glass powder & Hybrid beam with steel brush treatment of interface \\
\hline SB-GP & Waste glass powder & Hybrid beam with sand blast treatment of interface \\
\hline DH-GP & Waste glass powder & Hybrid beam with drill hole treatment of interface \\
\hline GR-GP & Waste glass powder & Hybrid beam with grooved treatment of interface
\end{tabular}

\section{TEST RESULTS AND DISCUSSION}

The behavior of the beams was examined in terms of load-mid span deflection curve, maximum compressive strain at the mid span point on the beam top surface and crack pattern of the beam. Figs. 5 and 6 show flexural performance of the beams. Considerable increase in the average toughness (absorbed energy by beam or area under load-deflection curve) has been observed in Fig. 7 with employing interfacial surface treatment especially sand blast. Accordingly, high average increase in toughness of $81.5 \%$ can be gained using this treatment in hybrid concrete beam in comparison to beams without treatment of interfacial surface. Furthermore, an average 
increasing of $60 \%$ in this flexural toughness is noted with using waste glass powder instead of silica fume due to increasing in flexural rigidity of the HSC part which made with reactive powder.

Fig. 8 illustrates the values of maximum compressive strain of the hybrid concrete beams. Low record of the average compressive strain was obtained for SB groups due to increase in rigidity of the beams with this interfacial surface treatment. It is worth to mention that the maximum strain for the control ordinary concrete beam is 0.002024 which is approximately similar to that of the hybrid beam with sand blast interfacial surface.
Cracking of the beams was investigated in term of transverse load at the initial cracking, crack width at failure and collapse crack mode as given in Figs. 9 and 10 and Table 6, respectively. High and reasonable magnitudes of average initial cracking load and crack width of beams were achieved with using sand blast interfacial surface treatment of hybrid beams. Flexural failure at collapse which is safer than other forms of cracking mode appeared also in the behavior of hybrid concrete beams with interfacial surface treated by sand blast.

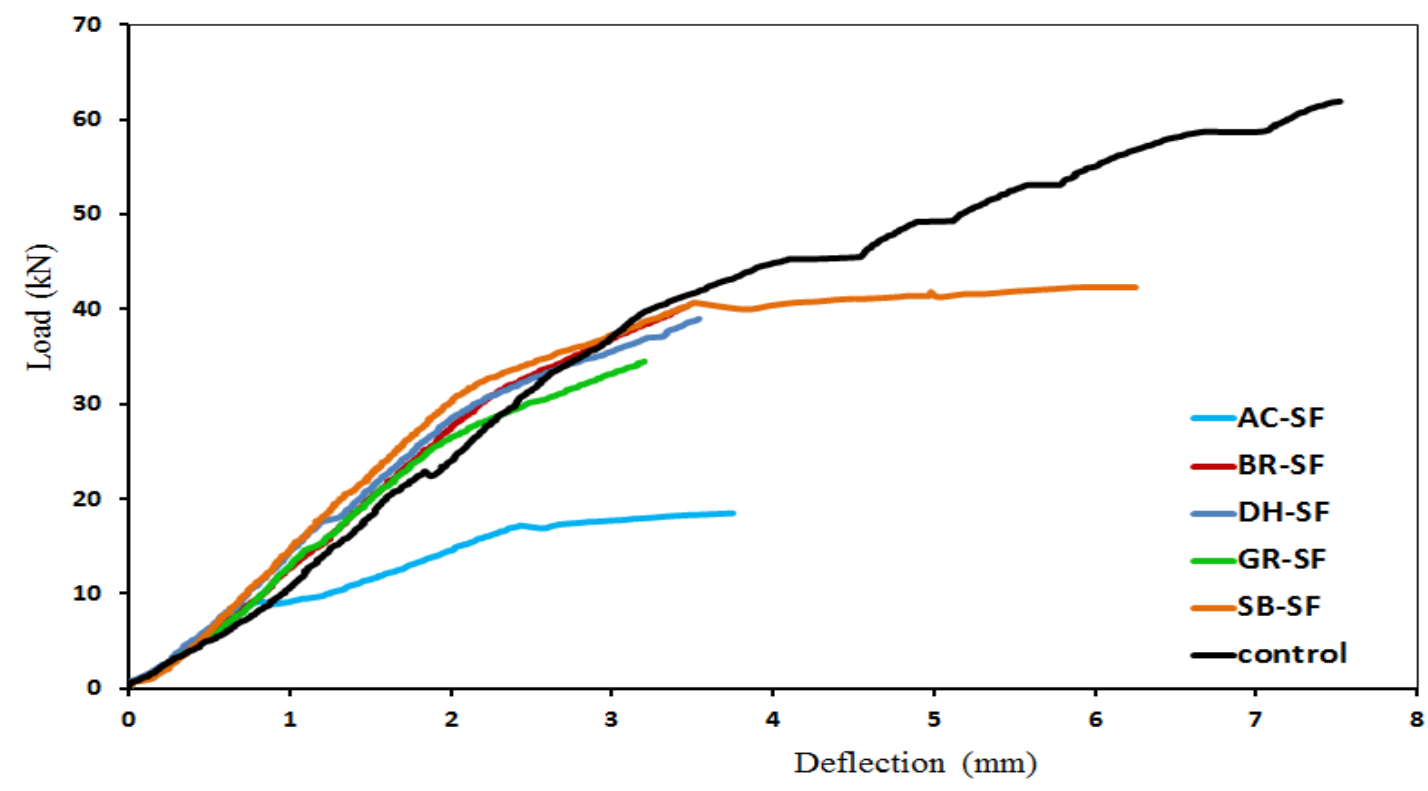

Fig. (5): Load-deflection behavior of hybrid beams made with reactive powder HSC and ordinary concrete

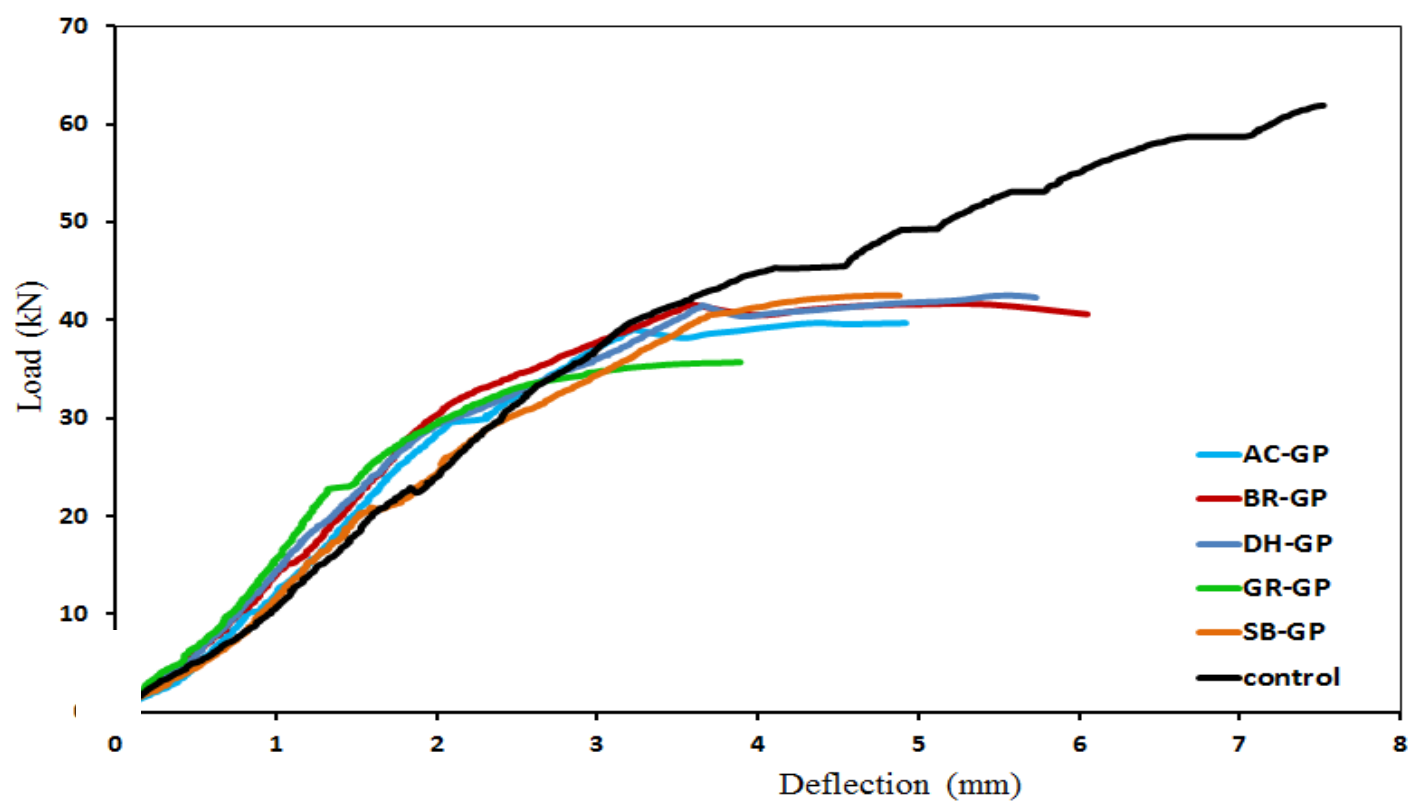

574 Fig. (6): Load-deflection behavior of hybrid beams made with inert powder HSC and ordinary concrete 


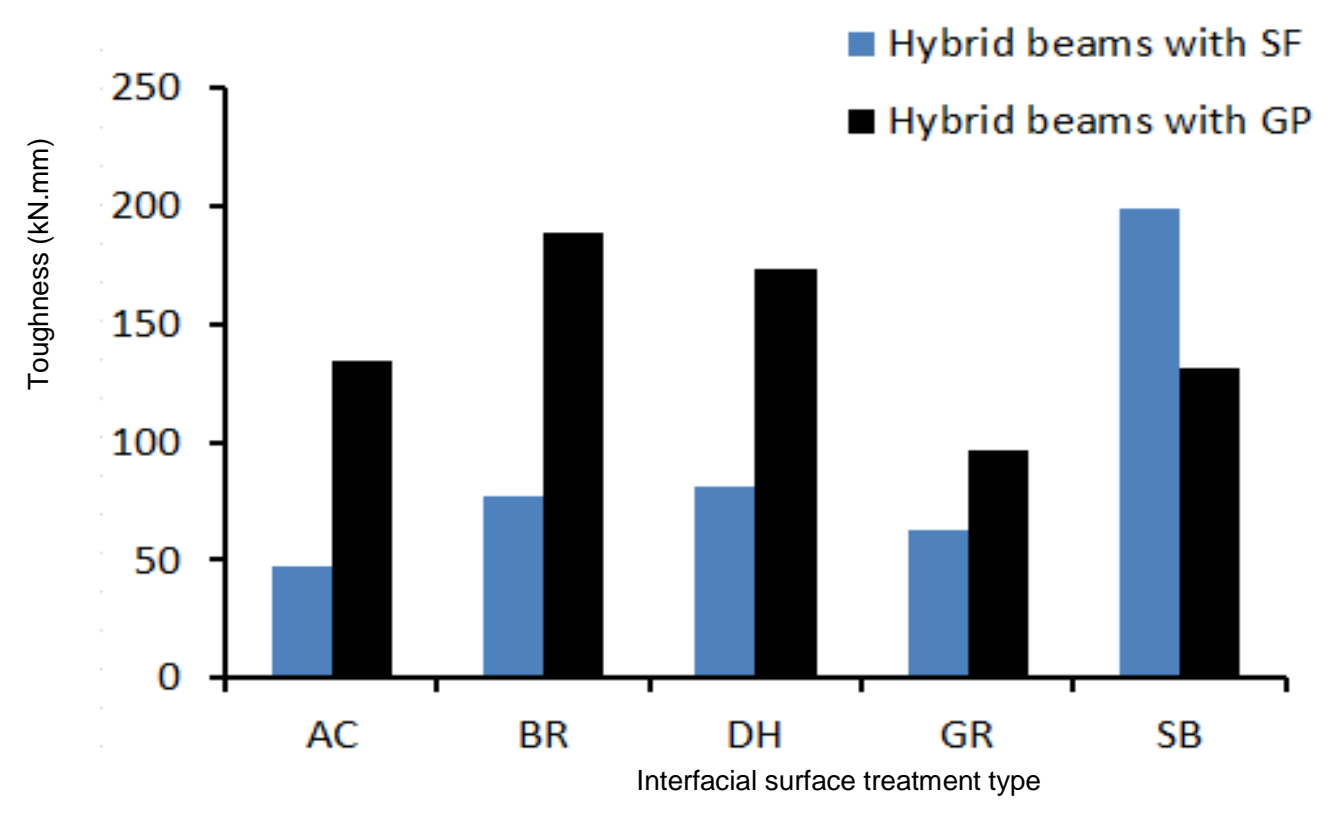

Fig.( 7): Toughness of the hybrid beams

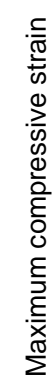

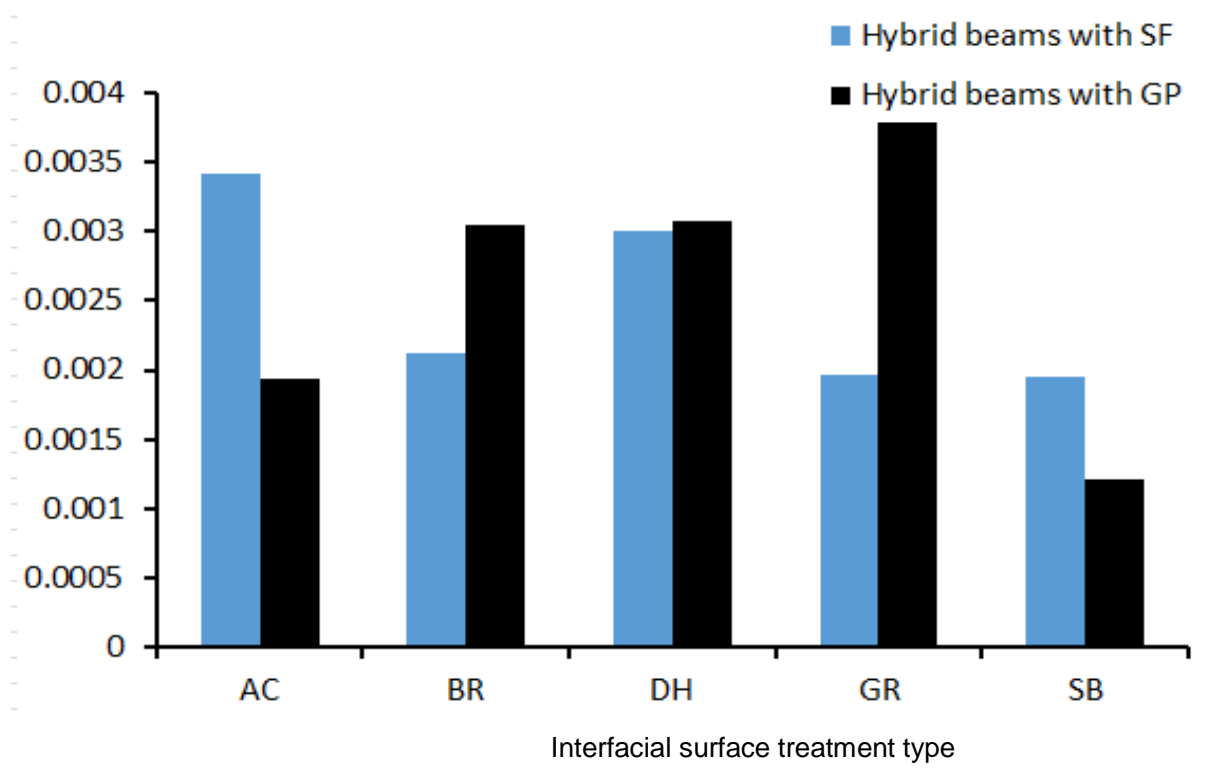

Fig. (8): Maximum compressive strain of the hybrid beams under transverse loading 


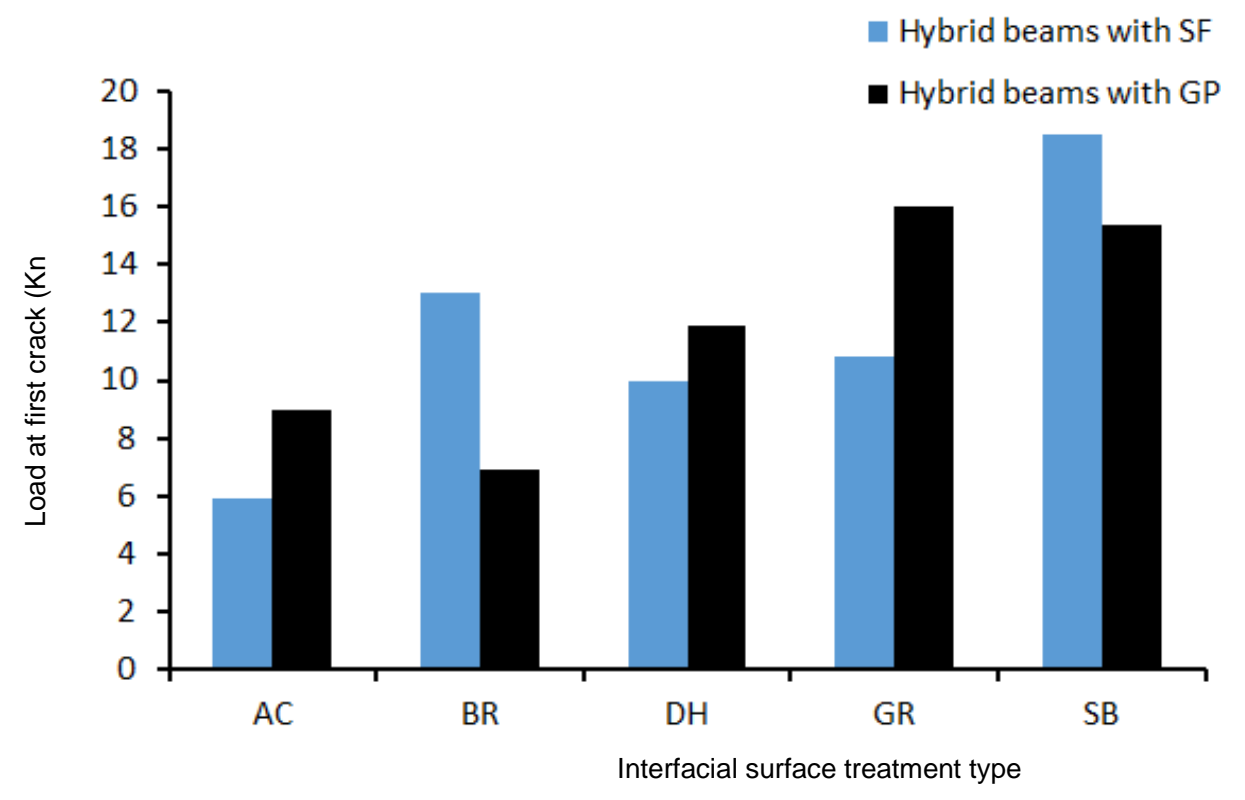

Fig. (9): Load at the first crack for the hybrid beams

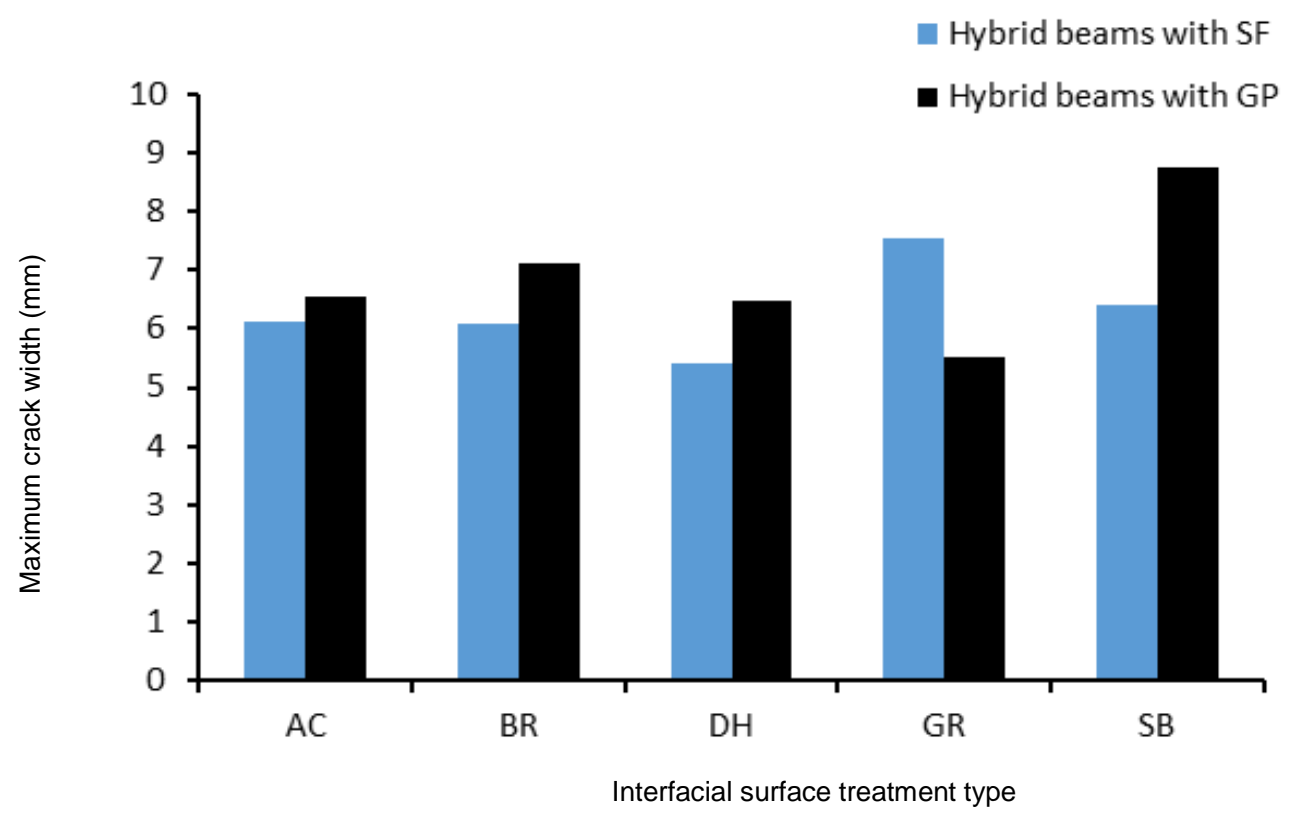

Fig. (10): Maximum crack width under loading for the hybrid beams 
Table(6): Crack pattern of the hybrid beams

\begin{tabular}{|c|c|c|}
\hline $\begin{array}{c}\text { Beam } \\
\text { designation }\end{array}$ & Crack type at collapse & Details \\
\hline AC-SF & $\begin{array}{c}\text { Interfacial and flexural } \\
\text { failure }\end{array}$ & \\
\hline BR-SF & Shear and flexural failure & \\
\hline SB-SF & Flexural failure & \\
\hline DH-SF & $\begin{array}{c}\text { Interfacial and flexural } \\
\text { failure }\end{array}$ & \\
\hline GR-SF & Interfacial and flexural & \\
\hline AC-GP & $\begin{array}{l}\text { Interfacial and flexural } \\
\text { failure }\end{array}$ & \\
\hline BR-GP & $\begin{array}{l}\text { Interfacial and flexural } \\
\text { failure }\end{array}$ & \\
\hline SB-GP & $\begin{array}{l}\text { Interfacial and flexural } \\
\text { failure }\end{array}$ & \\
\hline DH-GP & $\begin{array}{l}\text { Interfacial and flexural } \\
\text { failure }\end{array}$ & \\
\hline GR-GP & $\begin{array}{l}\text { Interfacial and flexural } \\
\text { failure }\end{array}$ & \\
\hline
\end{tabular}

\section{CONCLUSIONS}

In this study, the effect of the roughening mode of interfacial surface between deteriorated ordinary concrete and HSC in hybrid concrete beams on their flexural capacity has been examined. Reactive silica fume and inert waste glass powders were utilized in HSC fabrication. In addition, four types of treatments were adopted to improve the roughness of the surface as well as a control beam with no interfacial surface treatment.
The following conclusions have been drawn based on the aforementioned tests outcomes:

1- Waste glass powder plays great role in enhancing the average flexural toughness of hybrid beams rather than silica fume.

2- Present treatment methods (i.e. sand blast, steel bush, holes and grooves) of interfacial surface roughening induce an average enhancement more than $80 \%$ in hybrid beam toughness in comparison to that for hybrid beams with untreated interfacial surface. 
3- High flexural loading capacity of hybrid beams is achieved by sand blasted interfacial surface of hybrid beams made with reactive or inert powders. 4- Sand blasted surface between old and new concretes of hybrid beams with reactive powder delays their initial cracking; while this cracking is delayed in beams with waste glass powder using either sand blasted or grooved interfacial surfaces. 5- Reactivity of the used powders in HSC part of hybrid concrete beams does not affect the failure pattern at collapse except in beams with silica fume and sand blasted or steel brushed interfacial surface.

6- Brushed surface between HSC and OC produce dangerous sudden failure at collapse for beams with reactive powder; while sand blasted interfacial surface of hybrid beams with silica fume induce safest flexural failure mode for these beams.

\section{ACKNOLEDGEMENTS}

The authors are thankful to the College of Engineering, University of Duhok for providing some facilities of present research. Thank you very much goes also to Khder Khudayada, Kawa Shuker, Sabah Shuker and Dilgash Mustafa for their assistance.

\section{REFERENCES}

- Abu-Tair AI, Rigden SR, Burley E. Testing the bond between repair materials and concrete substrate. ACI Mater J 1996; (November-December):553558.

- Alaee FJ (2003). Retrofitting of reinforced concrete beams with CARDIFRC. Journal of Composites for Construction, Vol 7, p. 174.

- Alocer S, Jirsa J. Assessment of the response of reinforced concreate frame connections redesigned by jacketing. In: Proceedings of the Fourth US National Conference on Earthquake Engineering. vol. 3. May; 1990. p. 295-304.

- Alcocer SM. RC frame connections rehabilitated by jacketing. J Struct Eng 1993;119(5):1413-31.

- ASTM, Manual of aggregate and concrete testing. American society of testing and materials Vol. 04-02, 2007.

- Austin S, Robins P, Pan Y. Tensile bond testing of concrete repairs. Mater Struct 1995; 28: 249 259.

- Bett BJ, Klingner RE, Jirsa JO. Lateral load response of strengthened and repaired reinforced concrete columns. ACI Struct J 1988;85(5):499-508.
- Brühwiler E, Denarié E (2008). Rehabilitation of concrete structures using ultra-High Performance Fibre Reinforced Concrete. The Second International Symposium on Ultra High Performance Concrete, Kassel, Germany.

- Denarié E, Brühwiler E (2006). Structural rehabilitations wih ultra-high performance fibre reinforced Concrete. International Journal for Restauration of Buildings and Monuments, pp.453-467.

- Emmons PH. Concrete Repair and Maintenance. In: Part Three: Surface Repair, Section 6: Bonding Repair Materials to Existing Concrete. MA: R.S. Means Company; 1994. p. 154-163.

- Farhat F, Nicolaides D, Kanellopoulos A, and Karihaloo B (2007).High performance fiberreinforced cementitious composite (CARDIFRC)-Performance and application to retrofitting.Engineering Fracture Mechanics, Vol.74, No. (1-2), pp. 151-167.

- Farhat F, Nicolaides D, Kanellopoulos A, and Karihaloo B (2010).Behaviour of RC Beams Retrofitted with CARDIFRC after Thermal Cycling. Journal of Materials in Civil Engineering, Vol.22, No.21.

- Haleem, D. A., Kesserwani, G., and CaviedesVoullime, D. (2015). Haar waveletbased adaptive finite volume shallow water solver. Journal of Hydroinformatics. Vol. 17(6):857873

- Habel K (2004). Structural behaviour of composite UHPFRC-concrete elements.Doctoral Thesis, Swiss Federal Institute of Technology, Lausanne, Switzerland.

- Harris DK, Sarkar J, Ahlborn TM (2011). Interface Bond Characterization of Ultra-High Performance Concrete Overlays. Paper presented at the Transportation Research Board 90th Annual Meeting.

- Hindo KR. In-place bond testing and surface preparation of concrete. Concrete Int 1990; (April):127-129.

- Julio E. N.B.S., Branco F. A.B., Silva V. D. (2004). Concrete-to-concrete bond strength: Influence of the roughness of the substrate surface. Construction and Building Materials 18 (2004) 675-681.

- Ramirez J.L., Barcena J.M., Urreta J.I., e Sanchez J.A. Repair of concrete columns with partial localized damages. Report T 2.1 and $2.2 \mathrm{BREU}-$ 0186-C, April 1991.

- Rodriguez M, Park R. Seismic load tests on reinforced concrete columns strengthened by jacketing. ACI Struct J 1994;(MarchApril):150-159. 
- Rossi P (2002). Development of new cement composite material for construction, Innovation, and Developments in Concrete Materials and Construction.

- Santos and Julio (2011). Factors Affecting Bond between New and Old Concrete. ACI Materials Journal, 108(4).

- Sarkar J (2010). Characterization of the bond strength between ultra high performance concrete substrates.Master of Sciencei in Civil Engineering, Michigan Technological University.

- Saucier F, Pigeon M, Durability of new-to-old concrete bonding. In: Proceedings of the ACI International Conference Evaluation and Rehabilitation of Concrete Structures and Innovations in Design, Hong Kong. vol. 1. 1991. p. 689-707.

- Shin H-C., Wan Z. (2010). Interfacial Properties between New and Old Concretes. Second International Conference on Sustainable Construction Materials and Technologies, Ancona, Italy.
- Silfwerbrand J. Improving concrete bond in repaired bridge decks. Concrete Int 1990;(September):121-126.

- Stoppenhagen DR, Jirsa JO, Wyllie Jr LA. Seismic repair and strengthening of a severely damaged concrete frame. ACI Struct J, 1995;(MarchApril):177-187.

- Talbot C, Pigeon M, Beaupre D, Morgan DR. Influence of surface preparation on long-term bonding of shotcrete. ACI Mater J 1994;(November-December):560-566.

- Tayeh B. A., Abu Bakar B. H., Johari M. A. M., Voo Y. L. Mechanical and permeability properties of the interface between normal concrete substrate and ultra-high performance fiber concrete overlay. Construction and Building Materials 36 (2012) 538-548.

- Tayeh B. A., Abu Bakar B. H., Johari M. A. M., Voo Y. L. Utilization of ultra-high performance fibre concrete (UHPFC) for rehabilitation - a review. Procedia Engineering 54, 525-538, 2013. 